\author{
Ігор ОПАЦЬКИЙ, \\ orcid.org/0000-0002-6786-3295 \\ викладач кафедри історії Украӥни

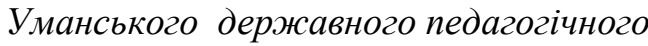 \\ Університету імені Павла Тичини \\ (Украӥна, Умань) \\ igor.opatskiy@gmail.com
}

\title{
ІСТОРИКО-АРХЕОЛОГІЧНИЙ НАРИС ПЕТРА КУРІННОГО «МІСТО ГУМАНЬ»: ПОВЕРНЕННЯ ДО ЧИТАЧА
}

\begin{abstract}
Висвітлено ключові віхи життя та інтелектуальної біографії відомого украӥнського археолога, історика, засновника Уманського краєзнавчого музею, одного з інічіаторів створення Української вільноі академї наук - П. Курінного. Особлива увага акцентується на «уманських» сторінках біографії вченого. До уваги читачів запропоновано перші дві частини історико-археологічного нарису Петра Курінного з історіі Умані «Місто Гумань», щзо опублікований 1952-1953 рр. в 4-х частинах діаспорного журналу "Авантард». Наведені в даній публікаиіі частини нарису містять оригінальне бачення історії заселення краю та знайомлять із найважливішими подіями історї Уманщини з найдавніших часів до початку Гайдамаччини.
\end{abstract}

Ключові слова: Умань, Петро Курінний, краєзнавство, археологія, украӥнська діаспора.

\author{
Ihor OPATSKIY, \\ lecturer of History of Ukraine Chair \\ Pavlo Tychyna Uman \\ State Pedagogical University \\ (Ukraine, Uman) \\ igor.opatskiy@gmail.com
}

\section{HISTORICAL AND ARCHAEOLOGICAL ESSEY OF PETRO KURINNYI «CITY OF GUMAN»: RETURN TO READERS}

Petro Kurinnyi's social activity and scientific work had been analyzed in the article. The main scientific achievements of the scientist in emigration were highlighted. The first archaeological excavations of Petro Kurinnyi and his formation as an archaeologist had been explored. The attention was also payed to the teacher of the history and geography of Uman Man's Gymnasium Danylo Shcherbakivskyi in his promoting the admiration of archeology and ethnography among students.

The author stated, that the first excavations on the territory of the Uman region, $P$. Kurin began while studying in the gymnasium. The study of the historical past of the Uman region had become much more active since 1913, when the Uman branch of the Kyiv Society for the Protection of Antiquities and Art appeared in Uman, and P. Kurinnyi was its member. Together with other members of the society P. Kurinnyi carried out archaeological excavations of the remains of the burial mounds in Kocherzhyntsi village. During these excavations, human remains, remnants of ceramics and metal jewelry were found.

The basic directions of scientific establishments' activity where P. Kurinnyi took an active participation, had been shown. The main scientific achievements of the scientist in emigration were highlighted. Collaboration with the Institute for the Study of the USSR had being analyzed. The Ukrainian editorial board of the Institute was headed by $P$. Kurinnyi and in the course of 10 years, in collaboration with a talented group of researchers, he edited 17 volumes of scientific works entitled "Ukrainian Collection". The scientific path of a scientist in the Ukrainian Free University, administrative positions and main works, prepared by P. Kurinnyi for publication, had been indicated.

The first two parts of the historical and archeological essay of Petro Kurinnyi on the history of Uman "City of Guman", published in 1952-1953 in four parts in the diaspora magazine "Avangard" had been analyzed. The 
parts of the mentioned essay contained an original view of the history of the region's settlement and introduced the most important events of the history of Uman from ancient times to the beginning of Haydamak rebelions.

Thus, we conclusion that the results of archaeological excavations of P. Kurinnyi in the Uman region from 1912 to the beginning of the 1930's were a significant contribution to the study of the region's past. Significant contributions had been made to the study of the settlements of Trypillian culture in the villages of Uman region.

Key words: Uman, Petro Kurinnyi, regional studies, archeology, Ukrainian emigrations.

Постановка проблеми. Історія м. Умань насичена багатьма різноманітними подіями, які відіграли знакову роль в історії України, неодноразово ставала предметом зацікавлень як вітчизняних, так i закордонних істориків. Значний внесок у вивчення минулого міста зробили історики-краєзнавці Х. Ящуржинський, О. Діденко, В. Стефанович Г. Храбан та ін. Їхня краєзнавча спадщина введена до наукового обігу, а інтелектуальна біографія стала предметом наукового інтересу сучасних дослідників (Сокирська, 2011). Однак перелік краєзнавчих досліджень Уманщини буде не повним без згадки вагомого творчого внеску Петра Петровича Курінного (1894 - 1972) у вивчення минулого краю.

Аналіз досліджень. На сьогодні дослідниками зроблено чимало у вивченні біографії П. Курінного. Основні віхи професійної та наукової біографії П. Курінного знайшли відображення у публікації С. Білоконя (Білоконь, 1998). Значний масив листування П. Курінного 3 колегами та рідними, насамперед батьком, введено до наукового оббігу Г. Станиціною (Станіцина, 2015). Ю. Торгало збагатив біографічні відомості про П. Курінного, опублікувавши частину матеріалів 3 родинного архіву Курінних (Торгало, 2014). Л. Пекарська окреслила основні напрямки діяльності П. Курінного у науковому житті української еміграції (Пекарська, 2009).

Виклад основного матеріалу. Ще 3 дитячого віку в П. Курінного, завдячуючи вчителю географії Данилу Щербаківському, формується інтерес до вивчення минулого Уманщини. Навчаючись в Уманській чоловічій гімназії він розпочинає систематичні дослідження краю, які включали археологічні розкопки, етнографічні експедиції та збір усноісторичного матеріалу. 31913 р. бере активну участь у діяльності Уманського відділення 
Київського товариства охорони пам'яток старовини i мистецтва ${ }^{1}$, метою діяльності якого було вивчення, популяризація та збереження пам'яті про історичне минуле краю. Після закінчення у 1917 р. Київського університету П. Курінний повертається до Умані та розпочинає педагогічну діяльність на посаді вчителя історії І Української Селянської гімназії ім. Б. Грінченка. Історичне минуле Уманщини не залишилося осторонь уваги молодого вчителя. Він збирав історичний матеріал, здійснював археологічні дослідження та долучав до цієї роботи гімназистів. Значна частина зібраного ними матеріалу лягла в основу заснованого при гімназії П. Курінним Соціально-історичного музею Уманщини. Зібравши значний масив історичного матеріалу та провівши низку археологічних досліджень на території Уманщини П. Курінний не встиг видати узагальнюючого історичного нарису про м. Умань. У 1924 р. він переїздить до Києва, де невдовзі очолює Державний історико-культурний заповідник «Всеукраїнський музейний городок» та продовжує керівництво археологічними експедиціями. Однак у 1933 р. проти Курінного порушено кримінальну справу, в наслідок якої вченому заборонялося 5 років працювати за фахом та публікуватися.

Переломним моментом в житті П. Курінного стала Друга світова війна. В окупованому Києві він працює науковим консультантом в Музеї-архіві переходової доби та заступником керуючого Музею до- і ранньої історії. Восени 1943 р. повертається до Умані де бере участь у вивезенні до Німеччини експонатів краєзнавчого музею (Торгало, 2014: 17).

Після еміграції в 1943 р. до Німеччини П. Курінний продовжив займатися науковою діяльністю та став членом низки наукових інституцій української діаспори: Український Вільний Університет, НТШ, УВАН, Науково Дослідний Інститут Української Мартирології, Українське

\footnotetext{
${ }^{1}$ Детальніше див. Опацький І.Ю. Уманське відділення Київського товариства охорони пам'яток старовини і мистецтва (за матеріалами родини Курінних) /І.Ю. Опацький // Емінак: науковий щоквартальник. - 2016. № 3 (15). - T. 4. - c. $96-101$
} 
Історичне Товариство, Інститут 3 вивчення СРСР та ін. ${ }^{2}$ Зібраний раніше історичний матеріал про Умань став основою для публікації у 1952-53 рр. у чотирьох номерах журналу Союзу Української Молоді «Авангард»³, у рубриці «Містами України», науково-популярного нарису з історії міста Умані «Місто Гумань». Цей нарис містить оригінальний погляд на минувшину нашого міста та кілька дискусійних тверджень. Однак не відомий для широкого кола вітчизняних дослідників. Тому пропонуємо ознайомитися 3 ним та запрошуємо до дискусії. Текст нарису публікуємо мовою оригіналу зі збереженням стилістичних та орфографічних особливостей.

П. Курінний Містами України. Місто Гумань (Курінний, 1952).

Багато є міст на нашій Україні, які змагаються поміж собою своєю давниною, старовиною, багатством, красою: Київ, Галич, Чернигів, Львів, Переяслав, Холм, Запорізькі Січі, Батурин, Чигирин, Чернівці, Ужгород, Люблин, Бужин, твердині Кам’янця... Ще більше міст втратило свої назви або сьогодні вже існують не під своїм власним ім'ям, хоч слава їх не менша від інших і досі витає далеко поза межами України, як світлий спогад героїчного нашого минулого: могутня колись Ольбія (нині село Парутине) твердиня України впродовж тисячі років, Шурукань (нині с. Богородицьке) страшна твердиня Половецької Землі, Лебедин, Немирів, Кам'янка, Пастирське і багато, багато інших.

Серед заслужених міст України мусимо згадати й столицю давньої Куманії (Гуманщини) місто Гумань.

$$
* * *
$$

\footnotetext{
${ }^{2}$ Детальніше див. Опацький І.Ю. Еміграційний період діяльності Петра Курінного // Емінак. - 2018. - № 2 (22) том 2. - С. 65-71

3 Журнал «Авангард» - орган Спілки Української Молоді (СУМ). Почав виходити з 1946 р. у м. Мюнхен. В різний період часу головними редакторами журналу були П. Кізко, П. Карпенко-Криниця, М. Кушнір, В. Шульга, Г. Наняк, О. Калинник, І. Крушельницький, В. Леник, Р. Зварич, О. Рожка. На сторінках видання публікувалися науково-популярні праці 3 українознавства, проблем виховання, подавалася інформація та хроніка з діяльності СУМ, розповідалося про визвольну боротьбу українського народу.
} 
Гуманщина - славнозвісний багатий кут степової України. Край цей розвинувся квітами...

Там де Ятрань круто в’ється,/ 3-під каменя б’є вода,/ Там дівчина Оля зветься,/ Хорошая, молода./ Ти дівчино, ти багата,/ В тебе батько й матір $\epsilon$, Двір широкий, хата біла,/ А що в хаті - все твоє./ А я бідний сиротина:/ Степ широкий - то мій сват,/ Шабля й піка - вся родина,/ Коник сивий - то мій брат!(Народна пісня, записана на Гуманщині).

Пишний той край свою назву має від осад зимовищ половецьких скотарів із племени куманів, що були на річці Умі-Гумі-Кумі (сучасна Гуманка), що тече через м. Гумань.

Гуманщина охоплює грунти й пасовиська річок Гнилого та Гірського Тикичів, Конели, Бабанки, Кам'янки, Гуманки, Сажової, Синиці, Синюхи, Ятрані та Удича.

Це старий козацький край, край Наливайка, Острожських, Сангушок, Гуманського полку, що підпирав старого Богдана Хмеля, його полковників Богуна, Гоголя, Зеленського, полковників Сербина, Сірка, Білогруда, гетьманів М. Ханенка, П. Дорошенка, Тетері, край М. Залізняка, Гонти. Край пишних розбудов Софії Потоцької, Аракчеєва. Край талановитої діяльности Михайла Комарова, П. Демуцького, митрополита В. Липківського.

Розкіш природи, заможність селян, зручні шляхи до Надчорномор'я завжди притягали на ті лани хижаків, що грабували та вбивали відвічних осельників, загарбували землю та зганяли людей з населених місць.

Ще й досі по містах, селах та лісах стоять руїни твердинь, замків та козацьких фортець, як от у Гумані, Торговиці, Косенівці, Мошурові, Старих Бабанах, Ягубці, Конелі, Охматові, Тальному, Маньківці, Краснопільці тощо.

Ще й досі риплять колеса по чумацьких шляхах: «Чорному», що йшов до Лукомор'я (Надчорномор'я), «Гардовому», що швиденько перебігав через Ягубець, Максимівну, перескакував через пороги ріки Бога на Рашків, а далі поза лозами прямував до Дунаю та Царгороду, та знаменитий шлях «Удич», що вже за княжих часів висилав чумацькі валки по сіль до Коломиї. 
Чорний ліс, холодний, грізний, непроглядний заступав, як і тепер заступає, їм дорогу.

Та й хороший той край Гуманщина, коли розцвіте й зазеленіє своїми 2040 різними квітами, як защебече сотками птахів, застрекоче, задзвенить i загуде безліччю мушок, комариків та коників або спочине над ставками Софіївки, коли повний місяць заллє сріблом тополі, берести та кучеряві верби по скелях та каміннях, відіб’є у воді пишну білу колонаду старого павільйону на так зв. «Острові Кохання», заіскриться самоцвітами на каскадах і водограях, зазирне через водяну завісу до «Храму Венери», в «люстерко Діяни», до «сімох струмочків», до «ужів», до «печери левії», на «Єлісейські луки», до «чотирьох братів», до обеліску «розбите життя», до ханських і турецьких альтанок із золотими рибами, і спиниться раптом перед однією з могутніх брил каміння, де в карти програно багато людей і хортів...

А вдень - сонця, сонця... Степ стелиться, мріє могилами, мигтить, мерехтить, пашить, марить тихими водами та перелісками, пахтить нивами й гречками і дихає чебриком та євшан-зіллям...

$$
* * *
$$

Гуманщина ніколи не була пусткою. В московській та польській літературі років зо двісті іï описують, як край колись безлюдний, пустий, нікому не належний, що був заселений i культивований лише заходами Польщі та Московщини.

Це неправда. Насправді Гуманщина ніколи не була пусткою. Викопані 3 гуманської землі рештки минулого життя - руїни осель, хат, речі вжитку свідчать, що на Гуманщині люди вже жили за яких 16.000 років перед народженням Христа, ще за життя тут великих слонів-мамутів, носорожців, печерних левів тощо. В часі від 10.000 до 4.000 р.р. перед Н. Хр. люди жили 3 рибальства, виготовляли вже випалений на вогні чудернацький посуд зі шпичастим дном, користувались до праці знаряддям із кремінних скалок, (наприклад, селище в Володимирівці, Білашках тощо). Від 4000 р.p. перед Н. Хр. аж до наших днів людність Гуманщини живе 3 хліборобства та 
тваринництва, будує свої селища й хати так само, як тепер наші люди роблять (хата глиняна 3 сіньми й піччю, 3 розмальованими долівками й стінами); селища - колом, з громадськими будівлями і святинями в середині. В культурі цих людей, що зветься тепер науково «трипільською», вже помічаємо багато таких виробів, які ще й тепер зустрічаються в побуті наших людей по українських селах і хуторах, як от посуд, глиняні статуетки, зображення одягу, їжа, звичаї.

Тими селищами Гуманщина засіяна вся вщерть. Наприклад, у с. с. Томашівці, Сушківці, Пеньожкові, Попудні, Красноставці, Колодистому, Кочержинцях, Талянках, Майданицькому і багатьох інших. Серед цих селищ трапляються такі багатющі, що їх можна вважати ніби за столиці цілого племени (напр., Володимирівка).

Від 1000 літ перед Н. Хр. ми надибуємо на знахідки т. зв. «білогрудівської культури», що ще користалась для хліборобства із кремінних серпів, для обрібки дерева - 3 кривих кремінних ножів, для шиття - 3 костяних шил, для обрібки шкіри - 3 костяних шкрябаків та доліт. Вже вживали також, як знаки старшин, роду, - булави 3 каменя, вже виробляли знаряддя з міді і бронзи; мали добрі мечі, сокири, списи, чингали, ножі та кам’яні келепи, такі, які потім були в ужиткові козаків-запоріжців. Правили людьми тоді родові князі, що на знак своєї влади мали вже корони і оздоби одягу та зброї з щирого золота. Отож Гуманщина, як і вся Україна в той час, була вже державною. Це була найстаріша державність, про яку збереглися вже перекази греків, так зв. «кіммерська». 3 того часу знайдено вже посуд місцевої роботи, на якому є письма. Україна вже тоді користувалася 3 письма.

Від 7-го сторіччя перед Н. Хр. на Україні 3’являються грецькі колоністи. Вони засновують серед нашої степової людности торговельні факторії-контори. 3 їх записів починаємо знати про Україну більше. На Гуманщині з того часу маємо могили князів (біля м. Гумані, с. Новосілок, Ризиної, Петраківки, Рижанівки, Линців) та просторі городища-зимовища 
(Кальник). Гуманщина належала до системи скитської держави на Україні. 3 часів від Р. Хр. до 7-го сторіччя на Гуманщині рясно розвинуті селища й цвинтарища хліборобської людности. Їх легко визначити в часі, бо в руїнах хат і в похованнях часто знаходяться римські або візантійські монети. Довший час вважали, що ці поховання належать готам, які в той час збройними ватагами захопили владу на Україні і заснували т. зв. «державу Германаріха». Але новіші досліди виявили, що таких поховань немає на прибалтійській батьківщині готів, звідки вони вирушили були на Україну. Думали, що то сармати. Нові розкопи показали, що сармати мають інші, відмінні поховання. Натомість виявлено, що такі поховання були вже й раніш на Україні, перед прибуттям готів і сарматів, і що вони потім збереглись аж до київської княжої держави і належали до культури давнього племени антів, яких частина дослідників вважає за слов'ян. Центральним осідком антів на Гуманщині, правдоподібно, було місто, від якого залишилось городище в с. Колодистому.

В кожному разі, в цей час Гуманщина була густо заселена і мала високу культуру (напр., хати з центральним опаленням).

Окремі знахідки з VII-X віків свідчать, що Гуманщина не була пусткою і в цей час. Візантійські й сасанідські (перські) гроші в розкопаних селищах, срібні речі слов'янського виробу, велика кількість черепків свідчать, що то рештки по старих господарях краю, а не по завойовниках.

Від X до XIII стор. ми маємо на Гуманщині дуже переконливі пам'ятки, що свідчать про іiі заселення. Знаємо столицю торків - село Торч, знаємо місто Куніль (сучасне с. Коман згадується в літописі під р. 1150), знаємо Удич, що згадується в 1165 р., правдоподібно існувала вже й Гумань, як столиця-зимовище половців-куманів. Знаємо також могили так зв. «половецького» типу коло м. Тального, з речами пограбованими в Києві. Такі ж могильники коло сіл Пилипів та Коржової. До трохи пізнішого часу належить городище в Торговиці. 
Це стверджує, що в часі Київської Руси - держави вел. князя Ярослава - Гуманщина входила в систему феодальних країв з густою людністю, і тому не дивно, що ії̈ боронив від татар литовський князь Ольгерд Гедиминович, погромивши татарів 1363 р. на р. Синюсі (Сині Води), а року 1497 князь Острожський, володар земель Гуманщини, та С. Наливайко погромили татар на р. Сороці та на верхів'ях р. Гуманки.

Напади татар примусили людність Гуманщини та їх володарів, - старі княжі українські роди Острожських, Четвертинських, Сангушок (1516) почати укріплення цього простору замками, що замикали б, «Чорний» та інші шляхи від півдня; це були замки Звенигород (коло сучасного с. Гудзівки), Торговиця на півдні, Гумань у центрі, Брацлав - на заході. Не підлягає також сумніву, що ці старі княжі маєтності не були пусткою, а навпаки, були повні сіл і міст.

Потреба захисту краю викликала до життя перші загони козацтва, борців проти насилля. Тут розпочалась діяльність С. Наливайка, князя К. Острожського, а маєтності Святополків-Четвертинських збереглись аж до большевицької влади. Двадцять три села Гуманщини, що згадані в архівних документах XVI стор. до цього часу зберегли свої назви. Окремі господарства сягали великого розміру, як от пасіка в с. Буках досягала 850 вуликів.

Року 1609 на Гуманщину прибуває з грамотою короля польського на володіння, «гуманською пустинею» пан староста брацлавський Валентин Калиновський. Хоч одержав він по королівській грамоті право на володіння на 7 миль маєтности, він насправді захопив 82 милі, а син його Мартин (1632 р.), як пишуть польські джерела, насадив тут вже біля 100 сіл та 10 містечок. Проте ці села й містечка мали старі половецько-українські назви.

МІСТО ГУМАНЬ (Продовження 3 Ч. I (23) (Курінний, 1953).

Польські агресивні політичні діячі - патріоти ідеї розбудовання Польщі за рахунок України - досі ширять думки про те, що лише від заволодіння українськими землями Польщею, після року 1569-го, почалося заселення їх 
та просякнення европейської культури на Україну. Одночасно московські загарбники до цього часу нав’язують свою теорію про те, що українці (галичани) лише в цьому часі почали переселюватися на Україну, що доти ніби належала лише Росіянам.

Обидві ці теорії є фальсифікатами.

Татарські напади ще в половині XV-го сторіччя сильно руйнували українські землі. Ці руйнацькі напади поставили перед українським населенням, що ніколи досі не залишило своїх предвічних земель, потребу обороняти ці землі. 3 цивільного населення утворюються козачі загони. Все життя краю перебудовується за оборонною системою: будуються нові замки в старих княжих городах, населення озброюється, утворюються лицарські братерства; виникають замки в Брацлаві, Винниці, Білій-Церкві, Черкасах, Каневі, Києві та Звенигородці. Ці замки будують старі українські княжі й боярські роди: Четвєртинські, Острозькі, Сангушки, Збаразькі. 3 того часу вже знаємо і поселення: Буки, Вороне, Мошурів, Романівку, Торговицю, що виникли зі старих княжих дворів і міст.

Отже бачимо Гуманщину (кол. Куманію) впорядкованим козачим краєм, мостом з Европи до Азії.

Лише після побудови замків, коли стало безпечніше під козацькою обороною, на Гуманщину почали через королівські надання насуватися ріжні авантурники-урядовці польські, підступно здобуваючи заселені землі від їх справжніх власників під назвою «пустинь».

Жадоба панів здобути чужі землі - завдячуємо ми той факт, що в жалуваних грамотах початку XVII стор. все частіше згадуються українські селища і міста, ніж то було досі. Окремі поселення сягали значних розмірів. Напр., місто Гумань 1629 р. мав 1067 «димів», що в них жило понад 6000 душ, населення себто «податкових» одиниць. По містах жили в 3635 «димах» біля 21.810 душ; сільської і податкової і людности було 15000 «димів» 9.000 душ. У підрахунок звичайно не попала значна кількість осіб, що їх не 
було оподатковано, чи мали якість пільги; напр., козаки, нові переселенці тощо.

Саме після появи тут польських урядовців починається соціальне безладдя: грабіжництво, катування населення, втеча 3 насаджених місць, повстання, посилення козаччини і постійні конфлікти з польською державою та її відпоручниками.

За таких умов не доводиться в польському колонізаційному рухові вбачати культуртрегерської місії польської держави.

Як злочинними були ті відомості, що подавали за своє господарювання польські старости свойому уряду, - королю видно хоч би з того факта, що староста Валентин Олександер Калиновський взяв собі на Гуманщині «пустиню», яку ревізори «обміряли» на сім миль. Проте польський історик Ол. Яблоновський відзначив, що ревізори «помилилися». Насправді грунт, який одержав В. Калиновський мав простір в 82,5 милі, себто майже в 12 разів більше. На цій «пустині» за 30 років «господарювання» Калиновського виявилося аж 100 сел та 11 містечок, що давали господареві біля 400.000 злотих річного прибутку (тепер на Уманщині 250 сел). Неправдивість відомостів Калиновських видно також ще і з того, що вони в своїй «пустині» набрали для походу в час волоської війни 40.000 війська. Одного збройного вояка за закликом про це мали постачити 3 самостійних господи. Отже загальна кількість самостійних господарств в той час мусила сягати щонайменше $120 \ldots$ Після такого ограбування місцевого населення матеріальний стан його сильно погіршав. От що оповідає про стан селянства на Україні француз - інженер польської коронної служби Г. Л. де-Боплан в його історико-географічному описові України 1648.

«Селяни там надзвичайно бідні, бо примушені працювати на поміщика і давати йому, відповідно до кількості посілої землі, багато мір збіжжя, безліч каплунів, курей, гусей та курчат до Великодня, Зелених Свят та Різдва. Крім того, селянин повинен возити для потреб володаря дрова і відбувати тисячну інших повинностей, які б він не повинен би був відбувати без заплати. Крім 
того, поміщики вимагають від селян грошової повинності, а також десятини від баранів, поросят, меду, усіх овочів і третього бика що три роки. Отже вони повинні віддати своєму господареві все, що той зажадає, так що не дивно, що ці нещасні, уярмлені в такі тяжкі умови, ніколи не можуть нічого надбати. Але це ще не так важливо, як те, що їх володарі користуються безмежною владою не лише над їх майном, але також над їх життям. Так велика $\epsilon$ свобода польської шляхти, яка живе мов в раю, а селяни перебувають в чистилищі. Тому, якщо випаде таким нещасним селянам попасти у кріпацтво до злого власника, то положення їх бува значно гірше, як положення каторжників на галерах.

Такими були «культуртрегери» на вільних українських землях напередодні Хмельниччини. Не дивно тому, що на заклик гетьмана Богдана Хмельницького Гуманщина піднялася вся. Свідок повстання, вороже наставлений до Хмельницького поляк, пише: «хлопська сваволя, почавши від Гуманя, таку гору бере, наче друге військо Хмельницького». Сталися криваві розправи з поляками у Немирові, Тульчині, Брацлаві, Вінниці, Гуманю, Красному та інших містах. Облогу Тульчина провадив Ганджа, полковник Гуманський. На Гуманщині повстанням керували отамани Кривоніс та Ганджа.

Цей великий визвольний рух підніс усі сили народні. Його оспівано в знаменитих думах козацьких, що з них одна згадує навіть Ярему Волошина Ганджу, полковника Гуманського.

Року 1649 на Гуманщину впав тягар — постачити харчами 70.000 війська Тугай-Бея, що стояло в Саврані та Чечельнику. Перебування польського і татарського війська на Гуманщині дуже обтяжувало людність через постійні грабунки, насильство і розправи. Року 1653 поляки захопили Ягубець, Мушурів, а року 1654 - Обозівку, Таланаївку, Орадівку, Христинівку. Польським військом провадив лютий ворог України Степан Чарнецький. Він обложив м. Гумань, де зачинилися полковники Іван Богун, Зеленський (Брацлавський) та Гоголь (Наддністрянський). Ст. Чарнецькому 
не пощастило взяти Гумані. Оборона була така сильна, що Чарнецькому довелося зняти облогу та поспішати до Охматова на бій 3 Богданом Хмельницьким. Бій біля Охматова відбувся в зимі на сильному морозі і він скінчився нічим, але від того, що бійці в час бою дуже мерзли, козаки назвали його «дрижипільським», а поле - «Дрижиполе».

Гуманський полк 1648 р. війська Богдана Хмельницького мав 2949 козаків і поділявся на 14 сотень. Козаки були більшістю місцеві, але були і 3 інших місць України: з Черкас, Запоріжжя, Винниці, Деражні, Немирова, Зборова, Любара, П’тигор та інш. Серед козаків є прізвище Золотаря, правдоподібно нащадка Митька Золотаря, що мав маєтності на уманщині вже з 1545 року. 3 полковників уманського полку знаємо трьох: Ганджу, Штепка та Осипа Глуха. От як виглядали міста уманщини в цей час:

«Город Шавулиха на реке на Тикичь Угосскомь; а по другою сторону река Шаулиха. Около слободь стоячей острогь; да вь тому острогу башня сь вороть проьзжая, за трои ворота. На городь на ряду: 2 пищали жельзныхь ядромь, по 2 гривенки, да обрывокь пещали жельзной. Землья и свинцу ньть». (Опис з реестру 1654 р. («Акты Южно Западной Россіи» т. Х.)

Ревізори подають ще про кількість козаків та міщан - 296, з них 193 міщанина та 103 козаків. Зазначається також уряди. Козацький уряд складався 3 сотника, отаманів, хоружого, осавула, військового писаря. Міщани мали бургомистра, війта. В Шавулисі були три церкви: Троїцька, Успенська, Михайлівська. («Записки Істор. Філологічного Відділу Української Академії Наук»).

Місто Гумань за описом Павла Алепського року 1633 було: «Першим великим містом Землі Козаків, що ми зустріли. Його будинки високі та гарні; здебільшого вони належали полякам, жидам і вірменам. Вони прикрашені численними круглими вікнами 3 різнокольорового шкла. Місто має дві фортеці, третю добудовують. В самому місті є багато польських палаців та ще 10 церков». Року 1668 в Гумані згадується манастир («Акты Юго-Зап. Pос.» УІІ стор. 78). 
Або, наприклад, місто Маньківка вразила Павла Олепського (року 1683) своїм розміром. Це було велике місто з 3-ма фортецями; в місті було 4 ставки. Міські будинки, що належали жидам і вірменам, гарні. В місті було 4 церкви, а поза містом - манастир. Найкраще враження справляв палац п. Калиновського («Путеш. патріарха Макарія» «Чтенія Моск. Об-ва», М. 1897, кн. IV.).

За Переславською угодою з Москвою з 1659 року московські гарнізони мусіли перебувати в Переяславі, Чернигові, Ніжині, Гумані і Брацлаві. До Гумані був призначений на воєводу Григорій Козловський. Проте, полковники Правобережної України відмовилися присягати на додержання умови: серед них був і полковник Гуманський, Михайло Ханенко.

В наслідок московських свавільств, що виявилися зараз же після підписання угоди, серед козацтва, старшини i населення з'явилися угруповання, що хотіли співпрацею 3 ріжними сусідніми державами визволити Україну з під Москви. На співпрацю з Польщею орієнтувалися: гетьман Іван Виговський, Михайло Ханенко, Юрій Немирич (з Тального), Тетеря, Опара тощо. На Туреччину сподівалися: гетьман Дорошенко, Суховієнко. За Москвою тягли: Іван Беспалий, Іван Сербин, гетьман Самойлович та інші.

Повстала жорстока війна; почалася гаряча втеча населення на Слобожанщину. Проти України була змова трьох: москалів, турків і поляків. Тактика руїни, грабіж людей (ясир), переселення їх на чужі землі, грабування й нищення майна, нищення економічне, пересварювання одних з одними, винищення найкращих людей в кривавій боротьбі і спільна акція для придушення спротиву $\square$ такий підсумок «культурної місії» Москви, Туреччини і Польщі на Україні, зокрема на Гуманщині. (Далі буде)

\section{СПИСОК ВИКОРИСТАНИХ ДЖЕРЕЛ І ЛІТЕРАТУРИ}

Білокінь, 1998 - Білокінь С. Курінний П.П.//Вчені Інституту історії України: Біобібліографічний довідник. К. 1998. С. 170-172. 
Курінний, 1952 - Курінний П. П. Місто Гумань // Авангард.1952. Ч 1 (23). С. 12-14.

Курінний, 1952 - Курінний П. П. Місто Гумань // Авангард.1952. Ч 2 (24). C. 15-17.

Пекарська, 2009 - Пекарська Л. В. Петро Курінний: повернення із забуття//Тематичний збірник наукових праць Національного музею історії України. Ч. 2. К. 2009. С. 94-105.

Сокирська, 2011 - Сокирська В. Історик Григорій Юхимович Храбан: життєвий шлях та наукова спадщина. Умань. 2011. 226 с.

Станіцина, 2015 - Станиціна Г. Особисте листування науковців як джерело свідчення про становище населення України у 20-ті - на початку 30х років XX ст. (за матеріалами Наукового архіву Інституту археології НАН України)// Матеріали і дослідження з археології Прикарпаття і Волині. 2015. Вип. 19. С. 170-180.

Торгало, 2014 - Торгало Ю. Петро Петрович Курінний. Умань. 2014. $134 \mathrm{c}$.

\section{REFERENCES}

Bilokin, 1998 - Bilokin S. Kurinnyi P.P.//Vcheni Instytutu istorii Ukrainy: Biobibliohrafichnyi dovidnyk. K. 1998. S. 170-172. [Scientists of the Institute of History of Ukraine: bibliographic guide]. K. 1998. S. 170-172. [in Ukrainain].

Kurinnyi, 1952 - Kurinnyi P. P. Misto Human // Avangard.1952. Ch 1 (23). S. 12-14. [City of Guman] Avangard.1952. Ch 1 (23). S. 12-14. [in Ukrainain].

Kurinnyi, 1952 - Kurinnyi P. P. Misto Human // Avangard.1952. Ch 2 (24). S. 15-17. [City of Guman] Avangard.1952. Ch 2 (24). S. 15-17. [in Ukrainain].

Pekarska, 2009 - Pekarska L. V. Petro Kurinnyi: povernennia iz zabuttia//Tematychnyi zbirnyk naukovykh prats Natsionalnoho muzeiu istorii Ukrainy. Ch. 2. K. 2009. S. 94-105. [P. Kurinnyi: Return from oblivion]. 
Tematychnyi zbirnyk naukovykh prats Natsionalnoho muzeiu istorii Ukrainy. Ch. 2. K. 2009. S. 94-105. [in Ukrainain].

Sokyrska, 2011 - Sokyrska V. Istoryk Hryhorii Yukhymovych Khraban: zhyttievyi shliakh ta naukova spadshchyna. Uman. 2011. 226 s. [Historian Grigory Khraban: Life Path and Scientific Heritage]. Uman. 2011. 226 s. [in Ukrainain].

Stanitsyna, 2015 - Stanytsina H. Osobyste lystuvannia naukovtsiv yak dzherelo svidchennia pro stanovyshche naselennia Ukrainy u 20-ti - na pochatku 30-kh rokiv KhKh st. (za materialamy Naukovoho arkhivu Instytutu arkheolohii NAN Ukrainy)// Materialy i doslidzhennia z arkheolohii Prykarpattia i Volyni. 2015. Vyp. 19. S. 170-180. [Personal correspondence of scientists as a source of evidence of the situation of the population of Ukraine in the 20's - in the early 30's of the twentieth century. (based on the materials of the Scientific Archive of the Institute of Archeology of the National Academy of Sciences of Ukraine)]. Materialy i doslidzhennia z arkheolohii Prykarpattia i Volyni. 2015. Vyp. 19. S. 170-180. [in Ukrainain].

Torhalo, 2014 - Torhalo Yu. Petro Petrovych Kurinnyi. Uman. 2014. 134 [Petro Petrovich Kurinnyi]. Uman. 2014. 134 s. [in Ukrainain]. 